\title{
WHAT MOTIVATES EUROPEAN \\ FIRMS TO ADOPT \\ ENVIRONMENTAL \\ MANAGEMENT SYSTEMS?
}

Jaime Rivera-Camino*

Universidad Carlos III de Madrid, Spain

The growing world concern about the impact of industrial activities on the environment has motivated companies to adopt Environmental Management Systems (EMSs). Despite this trend, very little has been written about the variables associated with the implementation of this type of management tool. This article describes the individual, strategic and organizational variables that a sample of European firms use to determine whether to adopt these EMS. It also discusses the most frequently used environmental standards, the outside influences that motivate directors to implement them and the personal perceptions that play a key role in determining whether the standards will be adopted.

* Correspondence to: Dr J. Rivera-Camino, Departamento de Económia de Empresa, Universidad Carlos III de Madrid, Calle Madrid 126, GETAFE 28903, Madrid, Spain.

\section{INTRODUCTION}

$\Lambda^{\text {lthoro }}$ though companies are affected by the growing worldwide opinion that environmentally harmful industrial activities should be curtailed, they are still hesitant to incorporate EMSs into their organizations. Our analysis of the situation revealed two main reasons for this low level of response: implantation of the system is often complicated by technical, personal and organizational impediments, and little theoretical and empirical research literature is available to corporate decision makers about the competitive advantages of using EMS.

Unlike the United States, which has produced most of the literature on EMS, Europe is lacking in scientific information. European firms must operate in global markets to remain competitive, and the European Union feels that, in order to do so, they should adopt Community standards for manufacturing processes and products. This would be an easy task for firms if it were not for the lack of research information on the European approach to EMSs. This article attempts to provide such information by explaining how variables are used in implementing environmental standards and to what extent selected firms actually apply them.

The study starts by discussing the impact of EMSs on commercial activity and the current status of implementation. This provides a theoretical framework for the relationships highlighted later in the work. The second part consists of the empirical analysis, which is 
followed by the results and a description of the methodology and finally a description of the main characteristics of the sample. The last section contains the conclusions and suggestions for future research.

\section{THEORETICAL FRAMEWORK}

\section{The importance of Environmental Management Systems}

There are various reasons why firms consider it necessary to use EMSs. The first is a reaction to the worldwide awareness of the importance of environmental protection and conservation, which is supported by governmental efforts to control industrially caused pollution (Larsson et al., 1996). The second reason is that consumers are also concerned about the environment, so firms are eager to convince them that their manufacturing and commercialization processes meet consumer environmental expectations. Specifically, firms want the public to know that they operate under EMSs, and that they are committed to achieving recognized environmental performance levels.

This pressure to use standards for manufacturing processes often motivates firms to build their own EMSs to meet the level of excellence established by external organizations (Welford and Gouldson, 1993) One such organization is the International Organization for Standardization (ISO), which develops numerous standards used by company managers to determine what their firms can do to achieve environmental performance levels (Randall, 1995).

Companies are under no obligation to abide by these standards, but if there are political and competitive advantages to be gained from the EMS, it is hoped that firms will voluntarily adopt them. The political advantages can be an incentive for EMS, since countries on every continent directly or indirectly support companies that use environmental standards. From a commercial standpoint, if firms respond to consumers' growing concern for environmental correctness, they can distinguish themselves from competitors and gain market advantage if customers buy from them because of the companies' commitment to a clean environment.

Companies can now choose between two environmental management schemes: EMAS (European Environmental Management Audit Scheme), which was developed by Community governmental agencies, and the ISO standards, which are promoted by business interactions (North, 1997). A significant part of our study focused on determining which EMS the participants in the survey preferred.

\section{Implementing Environmental Management Systems}

The literature and the survey participants indicate that despite the availability of various EMSs and the knowledge that such systems can be commercially advantageous, companies still find them difficult to implement. Managers agree that it is a formidable task to coordinate the large number of independent and interrelated variables that interact in this kind of a management system. For example, implementing an environmental scheme first requires a commitment on the part of top management to direct and promote the integration of activities from many functional areas (Klassen, 1993). The variables that come into play are described in Figure 1. The relationships among these variables are based on the concepts and principles drawn from the political economy framework. This states that the use of an EMS is the result of a process in which the main external and internal economic-political forces interact within an organizational system.

\section{Internal forces}

Business administration literature states that the individual perceptions of top management are becoming critical factors in formulating and implementing successful competitive strategies (Urban and Star, 1991). A number of authors consider these findings important enough to demand more theoretical and empirical research to identify the variables that motivate corporate directors to adopt EMSs (Drumwright, 1994). Managers have their own perceptions of environmental 

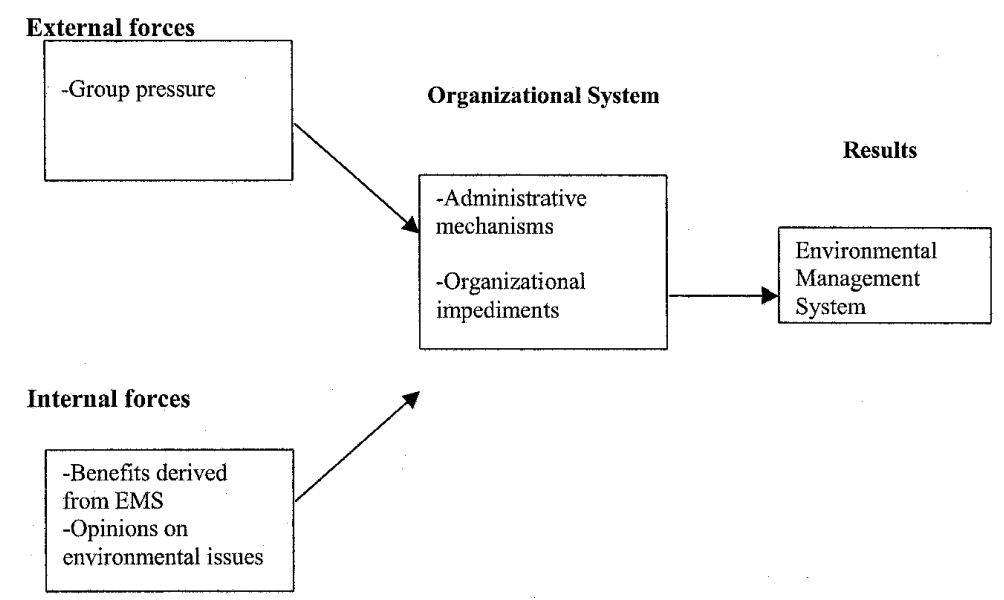

Figure 1. Process of implementing EMSs.

accountability, which influence the relationship between the external setting and group pressures (Naess, 1993).

\section{External forces}

Recent empirical studies reveal a positive correlation between the managerial perception of regulatory and institutional intensity and the level of green strategy in a business (Langerak et al., 1998). Because of this we thought it important to know top management's opinion about environmental issues, the pressures that motivate them to adopt EMSs and their forecasts for future benefits, since we surmised that these perceptions would influence the selection and implementation of environmental standards.

\section{Organizational system}

Business administration literature suggests that strategies can be formulated through the reorganization of the variables associated with organizational structure (Daft and Macintosh, 1984) and budget, training and compensation systems (Gómez-Mejía and Welbourne, 1988), as well as through the procedures used in the organization (Skivington and Daft, 1991).

Environmental literature suggests that the use of an EMS highlights the need to manage organizational dynamics, since the incorpora- tion of good environmental practices usually requires changes in organizational structure, the delegation of responsibilities, the training of personnel and the management of communications and control (Randall, 1995). It stands to reason then that organizational actions or routines must be clearly identified before EMS can be implemented.

\section{Organizational impediments}

The study of organizational dynamics should also focus on the variables that firms are unable to control, since these can create serious obstacles to implementing EMSs. Experts in project implementation (Pinto and Prescott, 1990) have identified several of these variables (derived from empirical studies), also described by Weimer and Vining (1989) in their analysis of public policy programmes. Examples include poorly defined objectives and goals, the lack of support by top management, no specification of the individual actions required by the project, the lack of required technology, the insufficient allocation of resources and the inadequate development of effective lines of communication among the staff. Given the diversity of these variables, we found it necessary to determine which of them actually affect EMS implementation. 


\section{EMPIRICAL ANALYSIS AND RESULTS}

\section{Description of the sample}

Data were collected using the Business Environmental Barometer, a standardized and structured questionnaire designed to accommodate the diversities among the 11 countries participating in the survey. The questionnaire was translated into the languages of the member countries of the Eurobarometer network.

Since the research focused on the analysis and comparison of national and international data, we were careful to define the populations used in the sampling procedure. Each country was asked to examine its own industrial structure in order to define the population from which the company participants would be chosen. The population consisted of companies classified according to criteria such as whether they were registered with the national stock exchange or had a workforce of more than ten employees. Once this phase was completed, each nation had to choose a representative sample of the firms for participation in the survey, which proved a challenge since domestic business structures varied widely among countries.

Likewise, each country determined its sampling procedure and a random sample was constructed (proportional or non-proportional stratified sample) that was valid for statistical analysis and would provide relevant information and interpretations. Once the selection process was completed, the survey and a cover letter were mailed to designated participants. The European average rate of response was $23 \%$, and 3051 firms (see Table 1) composed the sample of our study.

Table 1. Sample of European firms

\begin{tabular}{lllllllr}
\hline Country & $(n)$ & Country & $(n)$ & Country & $(n)$ & Country & $(n)$ \\
\hline Austria & 190 & Italy & 181 & Portugal & 300 & Switzerland & 250 \\
Belgium & 481 & Holland & 527 & Spain & 113 & Germany & 169 \\
France & 191 & Norway & 313 & Sweden & 336 & Total Sample & 3051 \\
\hline
\end{tabular}

Table 2. Companies under study, classified by country of origin and industrial sector

\begin{tabular}{|c|c|c|c|c|c|c|c|c|c|c|c|c|c|c|}
\hline \multirow[b]{2}{*}{ Country } & \multicolumn{14}{|c|}{ Industrial sectors } \\
\hline & 1 & 2 & 3 & 4 & 5 & 6 & 7 & 8 & 9 & 10 & 11 & 12 & 13 & 14 \\
\hline Austria & 19 & 14 & - & 22 & 11 & - & 22 & - & 4 & 9 & 28 & 27 & 8 & 23 \\
\hline Belgium & 41 & 49 & 1 & 24 & 11 & 3 & 38 & 31 & 18 & 77 & 19 & 15 & 5 & 28 \\
\hline France & 18 & 9 & 1 & 7 & 11 & 1 & 29 & 16 & 8 & 36 & 24 & 2 & 16 & 13 \\
\hline Italy & 12 & 24 & 5 & 9 & 5 & 4 & 11 & 11 & 7 & 19 & 21 & 12 & 2 & - \\
\hline Holland & 76 & 16 & 3 & 20 & 47 & 1 & 43 & 31 & 9 & 78 & 50 & 4 & 9 & 137 \\
\hline Norway & 52 & 20 & 3 & 31 & 50 & 4 & 7 & 10 & 12 & 46 & 45 & 28 & - & - \\
\hline Portugal & 37 & 64 & 12 & 11 & 10 & 1 & 6 & 13 & 26 & 29 & 10 & 8 & 3 & - \\
\hline Spain & 14 & 7 & 6 & - & 5 & 9 & 11 & 7 & 3 & 17 & 8 & 14 & 6 & 5 \\
\hline Sweden & 24 & 13 & - & 32 & 38 & 1 & 13 & 13 & 13 & 131 & 19 & 19 & 11 & - \\
\hline Switzerland & 28 & 11 & 1 & 9 & 19 & - & 19 & 14 & 3 & 39 & 32 & 37 & 2 & 12 \\
\hline Germany & 20 & 2 & - & 2 & 7 & 4 & 40 & 5 & 4 & 13 & 9 & 34 & 14 & - \\
\hline
\end{tabular}

1. Food, beverage, tobacco.

2. Textiles and textiles products.

3. Leather and leather products.

4. Wood and wood products.

5. Paper products, publishing and printing.

6. Coke, refined petroleum products and nuclear fuel.

7. Chemicals, chemicals products and man-made fibres.

Valid cases 2761 .
8. Rubber and plastic products.

9. Other non-metallic products.

10. Basic metals and fabricated metal products.

11. Machinery and equipment.

12. Electrical and optical equipment.

13. Transport equipment.

14. Other.

Missing cases 290. 
Table 3. Companies under study, classified by number of employees

\begin{tabular}{|c|c|c|c|c|}
\hline \multirow[t]{3}{*}{ Country } & \multirow{3}{*}{$\begin{array}{l}\text { No. of } \\
\text { responses }\end{array}$} & \multicolumn{3}{|c|}{ Company size } \\
\hline & & \multirow{2}{*}{$\frac{\text { Small }}{(<250)}$} & \multirow{2}{*}{$\frac{\text { Medium }}{(250-500)}$} & \multirow{2}{*}{$\frac{\text { Large }}{(>500)}$} \\
\hline & & & & \\
\hline Austria & 190 & 91 & 39 & 60 \\
\hline Belgium & 481 & 356 & 61 & 64 \\
\hline France & 191 & 78 & 21 & 92 \\
\hline Italy & 181 & 99 & 59 & 23 \\
\hline Netherlands & 527 & 401 & 64 & 62 \\
\hline Norway & 313 & 242 & 42 & 29 \\
\hline Portugal & 300 & 198 & 62 & 40 \\
\hline Spain & 113 & 26 & 36 & 51 \\
\hline Sweden & 336 & 293 & 43 & 0 \\
\hline Switzerland & 250 & 187 & 35 & 28 \\
\hline Germany & 169 & 17 & 21 & 131 \\
\hline Total & 3051 & 1988 & 483 & 580 \\
\hline
\end{tabular}

Fourteen manufacturing activities were selected: food and beverage, textiles, leather, wool products, paper products, coke and petroleum, chemicals, rubber and plastic products, other non-metallic products, basic metals, machinery and equipment, electrical, transport equipment and others (see Table 2).

Considering the number of employees, note that, except for Sweden, all of the countries have firms that fit the three size categories (see Table 3).

\section{Questionnaires}

The variables were assessed according to the following parameters.

The perception of pressure groups or environmental forces was analysed in relation to the forces (social group pressure, market variables, environmental regulations, directors and owners, unions, financiers and others) that influence companies to adopt environmental initiatives. The responses were ranked from 0 to 2 , with $0=$ no influence and $2=$ strong influence.

The section addressing the anticipated benefits derived from EMS also identifies the results of environmental actions (competitiveness, corporate image, costs savings, increased sales and others). Responses were ranked from 1 to 5 , with $1=$ very negative and $5=$ very posi- tive. For the sake of presentation and interpretation, they were then recoded to express the following views: $1 / 2$, disagree; 3 , indifferent; $4 / 5$, fully agree (with the estimated benefits of corporate environmental actions).

The opinion of top management on environmental issues was evaluated on a scale of 0 to 2 , with $0=$ disagree, $1=$ indifferent and $2=$ agree.

The organizational factors addressed a wide variety of administrative actions associated with the implementation of environmental standards. The evaluation of these organizational routines was based on a scale of 0 to 2 , where $0=$ no, $1=$ under consideration and $2=$ yes.

Firms responded to the questions regarding organizational obstacles or factors that prevent firms from implementing EMS by answering $0=$ little influence, $1=$ some influence and $2=$ high influence.

For the questions concerning the type of EMS used by the firms, participants were asked to indicate 'yes' or 'no' in the appropriate column for the EMAS or ISO 14001 scheme. A second question on the use of quality management systems (ISO 9000 series or similar) also required a 'yes' or 'no' answer.

Finally, the recoded responses were changed to percentages that reflected the differences among the choices of values on the scale. 
Table 4. Influence of pressure groups on EMS implementation

\begin{tabular}{lccc}
\hline Influence of pressure groups & \multicolumn{2}{c}{ Level of influence (\%) } \\
\cline { 2 - 4 } & None & Moderate & High \\
\hline National regulators & 7.4 & 9.1 & 83.5 \\
Owners, management, employees & 12.4 & 17.45 & 70.15 \\
International regulators & 17.3 & 18.2 & 64.5 \\
Voluntary agreements, local population, environmental organizations & 18.75 & 25 & 56.2 \\
Customers, competitors, consumer organizations, distributors, suppliers & 25.16 & 27.74 & 47.06 \\
Scientific institutions & 27.1 & 34.0 & 38.9 \\
\hline
\end{tabular}

\section{RESULTS}

Which are the major groups or forces that motivate companies to adopt Environmental Management Systems?

In this section we identify the pressure groups that most effectively motivate European firms to develop EMSs. The results summarized in Table 4 indicate that the most influential groups are the national regulations $(83.5 \%)$ and the directors and owners $(70.15 \%)$. The high percentages for these responses reveal the tremendous power that legal mechanisms and dominant coalitions have in influencing firms. In contrast, the third source of influence, international regulations, had a much lower impact with $64.5 \%$.

The fact that international regulations have a lesser impact indicates that European directors are still hesitant to recognize the global nature of pollution and the need for concerted action at the regional and international level. These results show the low effectiveness of European environmental politics. Despite Community efforts to address worldwide environmental problems (Art. 130 of the EC Treaty) and to promote the implementation of international rules and standards through the Fifth Environmental Action Programme for the internal market, these actions do not highly motivate firms to implement EMSs.

As in the case of international regulations, voluntary agreements and local population $(56.2 \%)$ exercise only a moderate influence on firms. Although initiatives such as the Fifth Environmental Action Programme encourage the use of voluntary agreements to obtain and allocate resources to solve industrial environ- mental problems, firms are usually not stimulated by these programmes.

A look at the market and corporate competitiveness factors reveals a moderate to low influence on directors $(47.6 \%)$, despite the fact that the European Commission has worked to promote environmental standards since 1992. The data also shows the low effectiveness of European environmental politics. Several reports ${ }^{1}$ by the Commission emphasize the relationship between environmental performance and competitiveness, and indicate a need to develop a strategy to rationalize environmental competitiveness. Nevertheless, we found that, in reality, firms were not highly motivated by these two factors.

What are the major benefits to be expected from using Environmental Management Systems?

According to the results in Table 5, directors considered EMSs to be more a way of improving corporate image and political relations than a method of acquiring long-term benefits. The percentages show that firms are not convinced that EMSs will increase productivity $(25.2 \%)$ or competitiveness $(35.1 \%)$, and they almost all agree that they do not add to short-term benefits $(18.7 \%)$.

European Union legislators should find these results revealing, since they confirm some of the doubts that existed about the effectiveness of EMSs at the time the Fifth Environmental Action Programme was

\footnotetext{
${ }^{1}$ Reports such as Industrial Competitiveness and Protection of the Environment (1992); Conclusions of 4 May1993; A Policy for the European Union on Industrial Competitiveness (1994); Industrial Cooperation with Central and Eastern European Countries, adopted March 1995
} 
Table 5. Anticipated benefits from EMS

\begin{tabular}{lcll}
\hline Reasons for using EMS & \multicolumn{3}{l}{ Percentages } \\
\cline { 2 - 4 } & Disagree & Indifferent & Fully agree \\
\hline Corporate image & 0.7 & 15.7 & 83.6 \\
Owner's and top management's satisfaction & 2.2 & 33.7 & 64.1 \\
Product image & 2.2 & 34.9 & 62.9 \\
Long-term profits & 11.7 & 32.4 & 55.9 \\
New market opportunities, sales, competitiveness & 6.1 & 58.8 & 35.1 \\
Productivity increase & 14.4 & 60.4 & 25.2 \\
Short-term profits & 32.3 & 49.0 & 18.7 \\
\hline
\end{tabular}

launched. The programme admitted that, although it would be necessary, it would not be easy to assess the costs and benefits of environmental measures. In view of this, we believe that the environmental effects of policies should be analysed and clarified before legislative measures are taken.

Which opinions on environmental issues most influence the implementation of Environmental Management Systems?

This section deals with top management's opinions on given aspects of environmental issues. The results in Table 6 indicate that the consensus among managers is that environmental problems are an important challenge to society $(80.6 \%)$.

Second in importance is the belief that environmental problems are solved by increased technological development. These results confirm the opinions of the White Paper on Growth, Competitiveness and Employment (1993), which suggests that future economic prosperity is associated with the creation of new, clean technology and that a pollution-free environment is a major element of a new model of social development.

The results also indicate that nearly $50 \%$ of the sample recognizes that employees are not well informed about the firm's environmental policy. This is an important finding, since business theory maintains that successful implementation depends on how thoroughly firms inform their employees about company strategies.

An interesting fact is that $50 \%$ of the directors maintain that neither legal measures or market mechanisms are capable of solving environmental problems. This opinion was also expressed in Resolution 55 (1997), which states that financial instruments are often more effective than the common legislative instruments of rules and prohibitions. In fact, financial instruments have several appealing properties, which, if properly designed, may promote environmentally friendly behaviour and penalize pollution.

Table 6. Directors' opinions on environmental issues

\begin{tabular}{|c|c|c|c|}
\hline \multirow[t]{2}{*}{ Environmental issues of greatest interest } & \multicolumn{3}{|c|}{ Percentages } \\
\hline & Disagree & Indifferent & Fully agree \\
\hline $\begin{array}{l}\text { Environmental problems are among the most important challenges } \\
\text { facing society }\end{array}$ & 8.5 & 10.9 & 80.6 \\
\hline $\begin{array}{l}\text { Environmental problems will be solved through technological } \\
\text { development }\end{array}$ & 22.0 & 16.1 & 61.9 \\
\hline Our employees are aware of our environmental policy & 21.1 & 23.7 & 55.2 \\
\hline $\begin{array}{l}\text { Stricter environmental regulations are needed to solve environmental } \\
\text { problems }\end{array}$ & 32.4 & 18.9 & 48.7 \\
\hline Environmental problems will be solved through market mechanisms & 41.6 & 24.8 & 33.6 \\
\hline $\begin{array}{l}\text { Customers are willing to pay slightly more for an environmentally } \\
\text { sound product }\end{array}$ & 53.9 & 21.8 & 24.3 \\
\hline
\end{tabular}


Another relevant finding is the high percentage of directors who believe that their customers are not willing to pay more for ecological products. This may explain why directors seldom take into consideration the influence of market mechanisms when they make decisions about EMSs. To counteract this, firms and Community agencies should actively seek better information on consumer preferences for ecological products.

Which routines or organizational mechanisms do firms use to implement Environmental Management Systems?

This section examines the extent to which European companies have established organizational actions to implement EMSs. According to theory, these actions coincide with a planned organizational design, which is a prerequisite for the successful implementation of any business strategy.

The results in Table 7 show that the level of development of these actions is moderate to low. Also, the majority of firms develop a reactive approach to implementing EMSs. This low level of activity is probably due to the fact that directors lack the scientific literature necessary to analyse whether the implementation process is as complex in theory and practice as is seems.

What are the major obstacles or impediments to implementing Environmental Management Systems?

The data in Table 8 reveals that European directors believe that all of the variables used in this survey, which are derived from current business administration literature, can be considered obstacles to implementing EMSs. The leading impediments are high costs and the lack of support from financiers, followed by unclear regulations, which, according to the Fifth Environmental Actions Programme, can be avoided if companies adopt a strong information policy. ${ }^{2}$

Another opinion that emerges from the study, and should be analysed in detail and brought to the attention of Community legislators, is that firms think that EMSs give them

${ }^{2} 4.8$ Public Information and Education - Fifth Environmental Actions Programme: Towards Sustainability (1998).

Table 7. Routines or organizational mechanisms used in EMS implementation

\begin{tabular}{llll}
\hline Type of routines or organizational mechanisms & \multicolumn{2}{l}{ Level of development (\%) } \\
\cline { 2 - 4 } & None & Moderate & High \\
\hline The company has a written environmental policy & 32.9 & 23.8 & 43.3 \\
The company carries out environmental auditing/reviewing & 35.6 & 21.2 & 43.2 \\
The company has a programme for achieving the environmental objectives & 38.8 & 23.3 & 37.8 \\
The company has an auditing system to check the functioning of the & 52.9 & 21.9 & 25.2 \\
$\quad \begin{array}{l}\text { environmental programme } \\
\text { The company publishes a separate environmental report }\end{array}$ & 63.8 & 12.4 & 23.7 \\
\hline
\end{tabular}

Table 8. Impediments to implementing EMSs

\begin{tabular}{llll}
\hline Factors that impede implementation & \multicolumn{3}{l}{ Level of impact (\%) } \\
\cline { 2 - 4 } & None & Moderate & High \\
\hline Too costly and lack of financial support & 2.2 & 35.05 & 62.75 \\
Unclear regulations & 1.6 & 40.8 & 57.6 \\
No competitive advantage/low demand for green products & 1.8 & 41.55 & 56.65 \\
Lack of human skilled resources/no feasible technical support & 2.15 & 41.5 & 56.25 \\
Difficulties in organizing/lack of management support & 1.6 & 50.25 & 48.1 \\
\hline
\end{tabular}


Table 9. The types of EMS and company preferences

\begin{tabular}{lll}
\hline Type of EMS & \multicolumn{2}{l}{ Percentages } \\
\cline { 2 - 3 } & No & Yes \\
\hline Certification EMAS & 74.6 & 25.4 \\
ISO 14001 & 25.4 & 74.6 \\
Quality standard ISO 9000 or similar & 38.7 & 61.3 \\
\hline
\end{tabular}

no advantages over competitors. In fact, their impression is that there is a weak demand for ecological products.

The lack of capable human resources is also an obstacle, but this is understandable since the environmental profession is relatively new. ${ }^{3}$

Which Environmental Management Systems do firms use most often?

This set of data reveals the firms' preferences for the type of EMS and the level of impact. The results in Table 9 indicate that $74.6 \%$ of the firms use the ISO 14001 standard, which is the preferred system in business interactions. Only $25.4 \%$ use EMAS, which is a favourite of government agencies and environmental regulators.

Finally, the responses to the question on quality standards for production showed that $61.3 \%$ of the firms prefer the ISO 9000 series or similar.

The data in Table 9 clearly indicates that directors prefer the ISO series to the Community standard, which is a tendency that Commission officials have noted with concern. The rules governing EMAS (Nos 3 and 18) say that the Commission should promote the competitiveness of environmental standards and the credibility of EMAS, as well as encouraging the comparability of the system among member states in order to guarantee its efficiency (Document 5999PC0313-1999).

\section{CONCLUSIONS}

The scarcity of literature published on the use of EMSs prompted us to analyse and dissemi-

\footnotetext{
${ }^{3}$ A study conducted in Spain revealed that company environmental managers enter their positions having had the following previous training/experience: accounting/finance, $4.50 \%$; computer literacy, $5.40 \%$; marketing, $6.30 \%$; operations, $31.53 \%$; others, $52.25 \%$.
}

nate the results of a study on EMSs conducted among selected European firms. Our findings show that Community legislation of EMSs has a moderate to low impact on the use of environmental standards. This fact should alert legislators to the need to identify the obstacles that prevent firms from implementing environmental standards, especially those issued by the European Union.

The results described in this work represent a preliminary contribution to the task of identifying the variables that directors and legislators must be aware of to successfully implement EMSs. The data can also be used in future causal studies on EMSs, and as a reference tool for firms interested in responding to growing environmental demands.

\section{REFERENCES}

Daft R, Macintosh N. 1984. The nature and use of formal control systems for management control and strategy implementation. Journal of Management 10: 43-66.

Drumwright M. 1994. Socially responsible organizational buying: environmental concern as a non economic buying criterion. Journal of Marketing 58(July): $1-19$.

Gómez-Mejía L, Welbourne T. 1988. Compensation strategy: an overview and future steps. Human Resource Planning 11: 173-189.

Klassen R. 1993. The integration of environmental issues into manufacturing: toward an interactive opensystems model. Production and Inventory Management Journal First Quarter: 82-88.

Langerak F, van der Peelen E, van der Veen M. 1998 Exploratory results on the antecedents and consequences of green marketing. Journal of the Market Research Society 40(4): 323-335.

Larsson R, Olsson-Tjärnemo $\mathrm{H}$, Plogner A, Östlund S. 1996. Market pull or legislative push: a framework for strategic ecological reorientation. Scandinavian Journal of Management 12(3): 305-315.

Naess A. 1993. The deep ecological debate: some philosophical aspects. In Environmental Philosophy, Zimmerman M, Callicot J, Session G, Warren K, Clark J (eds). Prentice-Hall: Englewood Cliffs, NJ; 193-212.

North K. 1997. Environmental Business Management. International Labour Office: Geneva.

Pinto J, Prescott J. 1990. Planning and tactical factors in the project implementation process. Journal of Management Studies 27(3): 305-327.

Randall R. 1995. Randall's Practical Guide to ISO 9000: Implementation, Registration and Beyond. AddisonWesley: Reading, MA.

Resolution 55. 1997. 4th session - draft resolution presented by Mr J. Leinen, Rapporteur, 4 June. The 
Congress of Local and Regional Authorities of Europe, Council of Europe.

Skivington J, Daft R. 1991. A study of organizational framework and process modalities for the implementation of business-level strategic decisions. Journal of Management Studies 28(1): 45-68.

Urban G, Star S. 1991. Advanced Marketing Strategy. Prentice-Hall: Englewood Cliffs, NJ.

Weimer D, Vining A. 1989. Policy Analysis: Concepts and Practice. Prentice-Hall: Englewood Cliffs, NJ.

Welford R, Gouldson A. 1993. Environmental Management and Business Strategy. Pitman: London.

\section{BIOGRAPHY}

Dr. Jaime Rivera-Camino obtained his MBA and a Doctorate of Economic Sciences at the
Catholic University of Louvain, Belgium. He is currently a psychology doctoral candidate at the Universidad de Comillas in Madrid.

Prior to becoming a professor at the Universidad Carlos III in Madrid, he worked as a Research Assistant in the Marketing Department of the Catholic University of Louvain. His research area is focused on market competitive strategies, green marketing and the analysis of organizational decision processes. He can be contacted at Departmento de Economía de Empresa, Universidad Carlos III de Madrid, Calle Madrid 126 - GETAFE 28903 (Madrid), Spain.

Tel.: + 349162496 18. Fax: + 34916249608 . E-mail: jrivera@emp.uc3m.es 